\title{
PENGENALAN CITRA SATELIT SENTINEL-2 UNTUK PEMETAAN KELAUTAN
}

\author{
Oleh \\ Nadya Oktaviani ${ }^{1)}$ dan Hollanda A Kusuma ${ }^{2}$
}

\begin{abstract}
RECOGNITION AND UTILIZATION OF SATELLITE IMAGE SENTINEL-2 FOR MARINE MAPPING. Sentinel-2 is a satellite launched by a collaboration between The European Commission and the European Space Agency in the Global Monitoring for Environment and Security (GMES) program. The satellite has a mission to scan the Earth's surface simultaneously at an angle of 180 each satellite with a 5-day temporal resolution with the same appearance on the equator and has a spatial resolution of $10 \mathrm{~m}, 20 \mathrm{~m}$, and $60 \mathrm{~m}$. There are 13 multispectral channels including VNIR and SWIR. Four channels with $10 \mathrm{~m}$ spatial resolution adapt with SPOT 4/5 and user's comply requirements for land cover classification. Six channels with $20 \mathrm{~m}$ spatial resolution becomes a requirement for other Level 2 processing parameters. Channels with $60 \mathrm{~m}$ spatial resolution are specified for atmospheric correction and cloud filtering (443 $\mathrm{nm}$ for aerosols, $940 \mathrm{~nm}$ for moisture, and 1375 for thin cloud detection). Based on these specifications, Sentinel-2 can be an alternative for users to obtain image data with spatial, temporal, radiometric, and spectral resolution is better than SPOT and Landsat. Sentinel-2 can be downloaded for free and easy by the general public. The existence of image by Sentinel-2 is expected to be used optimally, especially for remote sensing analysis in marine field.
\end{abstract}

\section{PENDAHULUAN}

Sentinel-2 merupakan satelit yang diluncurkan oleh kerjasama antara The European Commision dan European Space Agency di dalam program Global Monitoring for Environment and Security (GMES). Satelit ini diluncurkan untuk memantau kondisi permukaan bumi, sehingga mampu memberikan informasi kondisi terkini bumi dari angkasa untuk aplikasi lingkungan dan keamanan. Sentinel-2 dibuat dengan tujuan untuk memastikan kelanjutan misi Landsat 5/7, SPOT-5, SPOT-Vegetation dan Envisat MERIS yang sebentar lagi akan berakhir masa operasinya. Misi dalam menyediakan citra satelit beresolusi spasial dan temporal yang tinggi sehingga pengguna masih dapat memperoleh data pengindaian permukaan bumi terbaru (Verrelst et al., 2012).

Global Monitoring for Environment and Security merupakan inisiatif dari European Commision yang dirancang

\footnotetext{
1) Bidang Penelitian, Badan Informasi Geospasial

2) Pusat Pemetaan Kelautan dan Lingkungan Pantai, Badan Informasi Geospasial
} 
untuk membuktikan kemampuan dan kapasitas Eropa dalam penyedian dan penggunaan informasi pemantauan operasional untuk aplikasi lingkungan dan keamanan. Kapasitas ini terdiri dari tiga modul yang merupakan sistem fungsional GMES : (1) produksi dan diseminasi informasi untuk mendukung kebijakan Uni Eropa untuk Lingkungan dan Keamanan; (2) mekanisme yang diperlukan untuk memastikan dialog permanen antara semua pemangku kepentingan dan khususnya antara penyedia dan pengguna; dan (3) kerangka hukum, keuangan, organisasi dan kelembagaan untuk memastikan berfungsinya sistem dan evolusinya (Drusch et al., 2012)

Misi Sentinel-2 memastikan komitmen Eropa membantu dunia dalam kegiatan observasi bumi tetap berlanjut dengan menggunakan beberapa instrumen yang memiliki resolusi spasial dan spektral yang berbeda dengan resolusi temporal yang lebih cepat, serta area yang tercakup secara global. Keberadaan Sentinel-2 didesain secara khusus untuk membantu ilmuwan mempelajari dan memantau interaksi dan proses yang ada di bumi; menyiapkan strategi dalam menghadapi tantangan perubahan global yang sedang terjadi; serta mencapai tujuan pengembangan masyarakat (Societal Development Goals). Selain itu dengan adanya satelit ini diharapkan ilmuwan mendapatkan harmonisasi data dan produk keilmuan yang baru untuk mengembangkan, dan mengintegrasikan pemantauan langsung dengan pemodelan untuk memahami perubahan lingkungan regional dan global, dan menemukan solusi bagaimana cara untuk mengantisipasi, dan mengelola perubahan iklim yang merusak. Sentinel-2 memanfaatkan teknologi dan pengalaman yang diperoleh di Eropa dan Amerika Serikat untuk mendukung pasokan data operasional untuk layanan seperti manajemen resiko (banjir dan kebakaran hutan, penurunan dan tanah longsor), penggunaan/perubahan lahan, pemantauan hutan, keamanan pangan/ sistem peringatan dini, pengelolaan air dan perlindungan tanah, pemetaan perkotaan, bahaya alam, pemetaan terestrial untuk bantuan kemanusiaan dan pembangunan, serta pemantauan kondisi perairan darat dan laut (Berger et al., 2012; European Space Agency, 2017a).

Penggunaan citra satelit Sentinel-2 untuk bidang kelautan telah dilakukan dan sangat menjanjikan (Malenovský et al., 2012; Hedley et al., 2012). Namun, sayangnya informasi penggunaan Citra Sentinel-2 untuk bidang kelautan terutama di Indonesia masih kurang, karena satelit ini masih relatif baru. Padahal citra ini dapat diakses dan diunduh secara gratis. Oleh karena itu, tulisan ini dibuat untuk memberikan informasi kepada masyarakat mengenai satelit Sentinel-2, dan cara mendapatkan citranya.

\section{GAMBARAN MISI SATELIT SENTINEL-2}

\section{Satelit Sentinel-2 (Gambar} 1) memiliki misi menggabungkan kemampuan SPOT dan Landsat untuk memindai permukaan bumi yaitu (1) cakupan daratan global yang sistematis dari $56^{\circ} \mathrm{LS}$ hingga $84^{\circ} \mathrm{LU}$ termasuk perairan pesisir, laut Mediterania, dan 
Antartika; (2) resolusi temporal tinggi yaitu setiap 5 hari di khatulistiwa dengan kondisi penampakan yang sama; (3) multi resolusi spasial yaitu $10 \mathrm{~m}, 20 \mathrm{~m}$, dan 60 m; (4) 13 kanal multispektral termasuk VNIR dan SWIR; (5) bidang pandang yang luas yaitu $290 \mathrm{~km}$. Satelit sentinel-2 terdiri dari 2 satelit kembaryang memindai permukaan bumi secara simultan pada sudut $180^{\circ}$ tiap satelitnya (Gambar 2). Orbit satelit ini Sun-synchronous pada ketinggian $786 \mathrm{~km}$ dengan inklinasi $98,62 \circ$ dan mengindai pada pukul
10:30 AM Local Time Descending Node (LTDN). Waktu lokal ini dipilih sebagai kompromi terbaik antara kebutuhan data dengan tutupan awan yang minimal dan untuk memastikan pencahayaan matahari yang sesuai. Waktu lokal Sentinel-2 mirip dengan SPOT dan Landsat, sehingga memungkinkan untuk mengkombinasikan data Sentinel-2 dengan data citra SPOT dan Landsat yang lama untuk kepentingan analisis time series (Drusch et al., 2012; European Space Agency, 2015).

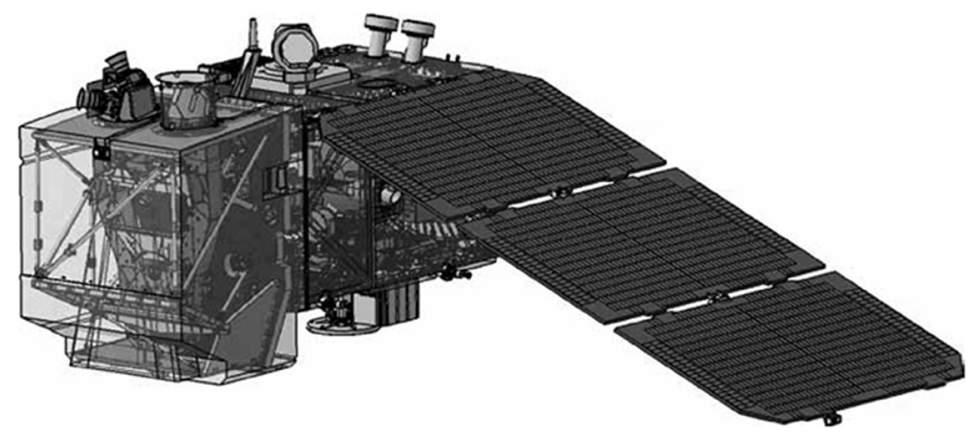

Gambar 1. Satelit Sentinel 2 (Astrium GmBH) Sumber : European Space Agency (2012)
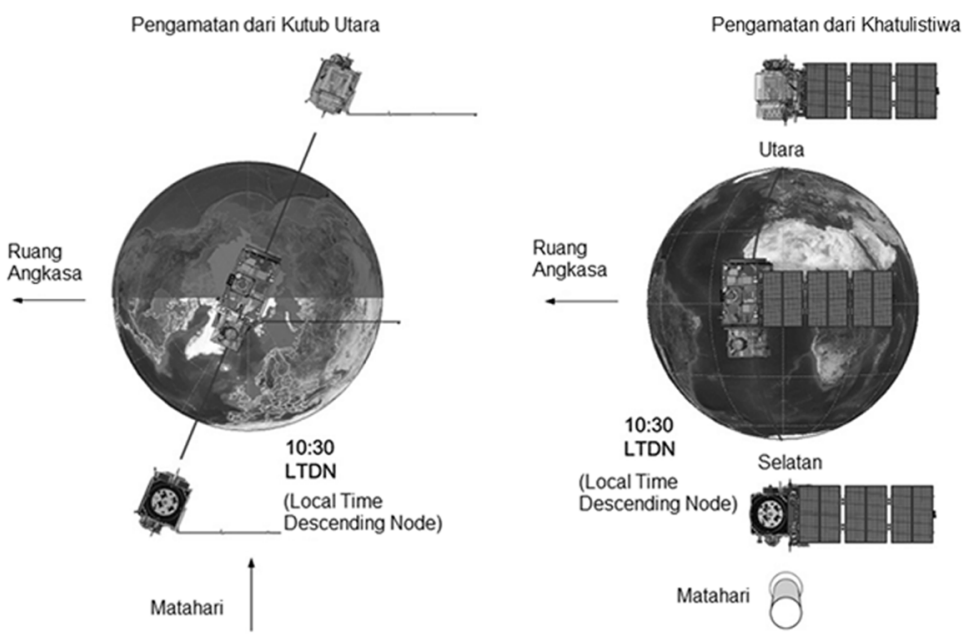

Gambar 2. Konfigurasi orbit satelit Sentinel-2 (Astrium-GmBH) Sumber : Drusch et al. (2012) 
Satelit Sentinel-2 direncanakan meluncur pada akhir 2013, namun peluncuran ini baru terlaksana pada 23 Juni 2015 untuk Satelit Sentinel-2A dan pada 7 Maret 2017 untuk Satelit Sentinel2B. Sentinel-2A diluncurkan oleh Roket Vega dari Kourou, Guyana Perancis dan Sentinel-2B diluncurkan oleh Rockot dari Plesetsk, Rusia. Pengindaian permukaan bumi yang dilakukan oleh Sentinel-2 harus memenuhi kriteria berikut ini : (1) daratan dengan luas lebih dari $100 \mathrm{~km}^{2}$; (2) daratan dan pulau yang berada di Benua Eropa; (3) pulau-pulau lain yang berada pada radius $20 \mathrm{~km}$ dari garis pantai daratan utama; (4) Laut Mediterania; (5) semua permukaan air di daratan; (6) semua laut yang tertutup (European Space Agency, 2012; European Space Agency, 2015; European Space Agency, 2017a; European Space Agency, 2017b).

Satelit Sentinel-2 memiliki bobot seberat 1,2 ton dan akan beroperasi selama 7,25 tahun. Masa hidup satelit ini telah ditambahkan melalui baterai dan propelan hingga 12-15 tahun. Seluruh sistem satelit Sentinel-2 dikembangkan oleh konsorsium industri di bawah Astrium GmBH-Jerman. Pembuatan instrumen multispektral dilakukan oleh Astrium SAS di Perancis (European Space Agency, 2015).

\section{SPESIFIKASI KANAL SATELIT SENTINEL-2}

Kanal Satelit Sentinel-2 dibuat dengan mengacu pada kanal-kanal yang terdapat pada SPOT dan Landsat. Perubahan lebar kanal dan penambahan kanal dilakukan pada Sentinel-2 untuk menyempurnakan performa dalam observasi bumi. Cakupan spektrum tiap kanal dan resolusi spasial dari Sentinel 2, SPOT, dan Landsat dapat dilihat pada Gambar 3.

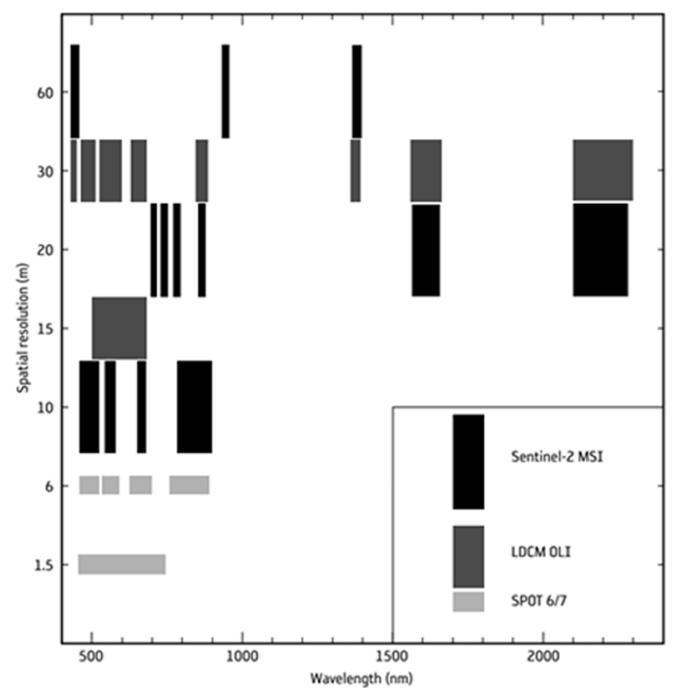

Gambar 3. Resolusi spektral kanal dibandingkan dengan resolusi spasial pada satelit Sentinel-2 MSI, LDCM OLI, dan SPOT 6/7. Ketinggian bar diskalakan dengan lebar sapuan satelit. Lebar sapuan Sentinel-2 sebesar 290 km, LDCM OLI $185 \mathrm{~km}$. 
Tiga belas kanal yang dipasang pada satelit Sentinel-2 memiliki karakteristik tersendiri (Tabel 1). Empat kanal dengan resolusi spasial $10 \mathrm{~m}$ memastikan kesesuaian dengan SPOT 4/5 dan memenuhi persyaratan pengguna untuk klasifikasi tutupan lahan. Resolusi spasial $20 \mathrm{~m}$ yang dimiliki oleh 6 kanal menjadi persyaratan untuk parameter pengolahan level 2 lainnya. Kanal dengan resolusi spasial $60 \mathrm{~m}$ dikhususkan untuk koreksi atmosfer dan penyaringan awan (443 nm untuk aerosol, $940 \mathrm{~nm}$ untuk uap air, dan 1375 untuk deteksi awan tipis). Resolusi sebesar $60 \mathrm{~m}$ dianggap cukup untuk menangkap variabilitas spasial parameter geofisika atmosfer (Drusch et al., 2012).

Tabel 1. Spesifikasi teknis kanal pada Sentinel-2 (dimodifikasi dari van der Meer et al., 2014 dan Drusch et al., 2012)

\begin{tabular}{|c|c|c|c|c|c|c|}
\hline $\begin{array}{l}\text { Nomor } \\
\text { kanal }\end{array}$ & $\begin{array}{l}\text { Panjang } \\
\text { gelombang } \\
(\mathbf{n m})\end{array}$ & $\begin{array}{l}\text { Lebar } \\
\text { kanal } \\
(\mathrm{nm})\end{array}$ & $\begin{array}{c}\text { Lref } \\
\left(\mathrm{Wm}^{-2} \mathbf{s r}^{-1} \mu \mathrm{m}^{-1}\right)\end{array}$ & $\begin{array}{l}\text { SNR } \\
\text { @Lref }\end{array}$ & $\begin{array}{l}\text { Resolusi } \\
\text { Spasial } \\
\text { (m) }\end{array}$ & Kegunaan \\
\hline 1 & 443 & 20 & 129 & 129 & 60 & Koreksi atmosferik (hamburan aerosol) \\
\hline 2 & 490 & 65 & 128 & 154 & 10 & $\begin{array}{l}\text { Perkembangan vegetasi, karotenoid, } \\
\text { keadaan tanah, koreksi atmosferik } \\
\text { (hamburan aerosol); }\end{array}$ \\
\hline 3 & 560 & 35 & 128 & 168 & 10 & $\begin{array}{l}\text { Puncak sinar hijau, sensitif terhadap } \\
\text { total klorofil pada vegetasi }\end{array}$ \\
\hline 4 & 665 & 30 & 108 & 142 & 10 & Absorpsi klorofil maksimum \\
\hline 5 & 705 & 15 & 74,5 & 117 & 20 & $\begin{array}{l}\text { Konsolidasi koreksi atmosferik/ dasar } \\
\text { flioresensi, posisi tepi kanal merah }\end{array}$ \\
\hline 6 & 740 & 15 & 68 & 89 & 20 & $\begin{array}{l}\text { Deteksi batas warna merah; koreksi } \\
\text { atmosferik; penerimaan beban aerosol }\end{array}$ \\
\hline 7 & 783 & 20 & 67 & 105 & 20 & Indeks area daun, tepi puncak NIR \\
\hline 8 & 842 & 115 & 103 & 174 & 10 & Indeks area daun \\
\hline $8 b$ & 865 & 20 & 52,5 & 72 & 20 & $\begin{array}{l}\text { Puncak NIR yang sensitif dengan total } \\
\text { klorofil, biomassa, Indeks tepi daun } \\
\text { dan protein; referensi penyerapan uap } \\
\text { air; penerimaan beban dan tipe aerosol }\end{array}$ \\
\hline 9 & 945 & 20 & 9 & 114 & 60 & $\begin{array}{l}\text { Koreksi atmosferik untuk mengetahui } \\
\text { absorpsi uap air }\end{array}$ \\
\hline 10 & 1380 & 30 & 6 & 50 & 60 & $\begin{array}{l}\text { Koreksi atmosferik untuk mengetahui } \\
\text { awan yang tipis (cirrus) }\end{array}$ \\
\hline 11 & 1610 & 90 & 4 & 100 & 20 & $\begin{array}{l}\text { Sensitif terhadap lignin, pati dan hutan } \\
\text { di atas biomassa tanah; pemisahan } \\
\text { salju/ es/ awan }\end{array}$ \\
\hline 12 & 2190 & 180 & 1,5 & 100 & 20 & $\begin{array}{l}\text { Penilaian kondisi vegetasi; pembedaan } \\
\text { tanah liat untuk pemantauan erosi } \\
\text { tanah; perbedaan antara biomassa } \\
\text { hidup, mati dan tanah. }\end{array}$ \\
\hline
\end{tabular}




\section{CARA MENDAPATKAN CITRA SENTINEL-2}

Citra Sentinel-2 dapat diperoleh melalui United States Geological Survey (USGS) Earth Explorer web (http:// earthexplorer.usgs.gov),

Sentinels

Scientific Data Hub (https://scihub. copernicus.eu/), atau Earth Observing System (https://lv.eosda.com/). Citra yang dapat diunduh merupakan produk citra Level $1 \mathrm{C}$ dengan luas $100 \mathrm{~km}^{2}$ yang telah di ortho ke dalam proyeksi UTM/WGS84. Produk ini dihasilkan menggunakan Digital Elevation Model (DEM) untuk memproyeksi citra ke dalam koordinat kartografik. Pengukuran radiometrik tiap piksel citra disediakan dalam satuan reflektansi Top of Atmosphere (TOA) pada semua parameter untuk diubah menjadi radiansi (European Space Agency, 2015). Jadi, citra level 1C telah dilakukan koreksi geometrik dan radiometrik sistematis oleh pihak Sentinel.

Berikut ini akan diberikan langkah-langkah untuk mendapatkan citra Sentinel-2 melalui Earth Explorer dan Earth Observing System.

\section{via USGS}

1. Buka situs http://earthexplorer.usgs.gov

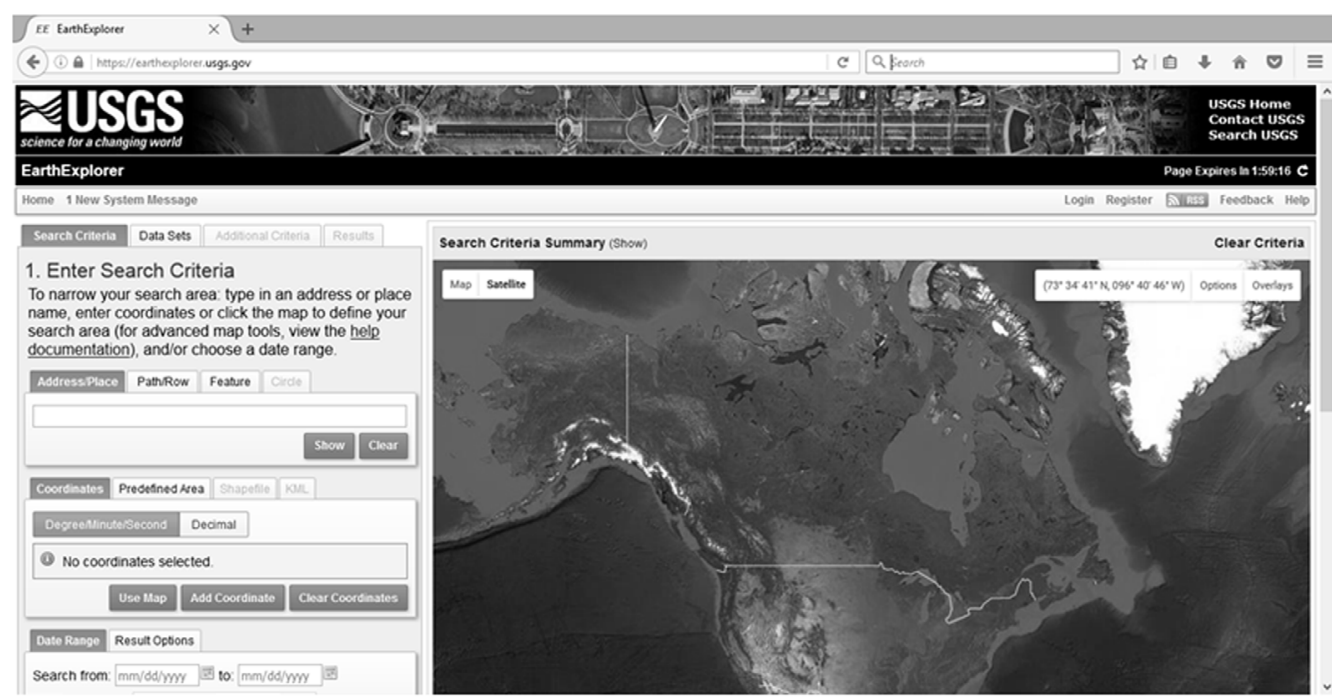

Gambar 4. Situs USGS EarthExplorer (https://earthexplorer.usgs.gov/)

2. Pilih Login bagi yang telah memiliki akun, atau Sign Up bagi yang belum memiliki akun. Buat akun dengan mendaftarkan alamat email anda yang akan digunakan untuk melakukan verifikasi akun. Pengguna baru bisa mengunduh citra satelit apabila sudah melakukan registrasi dan login.

3. Setelah melakukan login maka akan muncul nama pemilik akun pada sisi kanan atas pada tampilan layar browser. 


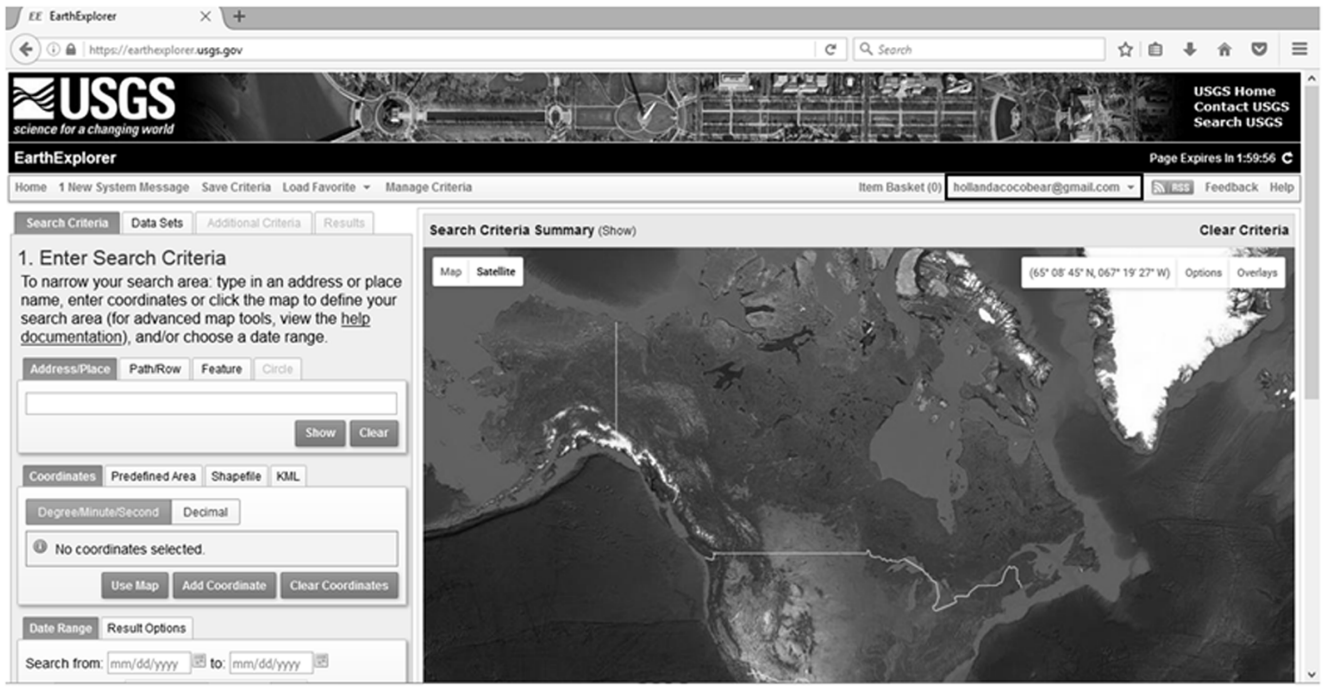

Gambar 5. Tampilan EarthExplorer setelah pengguna melakukan login

4. Pengguna mencari daerah yang ingin diunduh data citra satelit. Sebagai contoh daerah Kepulauan Seribu. Pengguna bisa menggeser dan melakukan zoom in pada peta di sisi kanan dan diposisikan sesuai area yang diinginkan. Kemudian tekan tombol Use Map yang berada di bagian sisi kiri jendela browser.

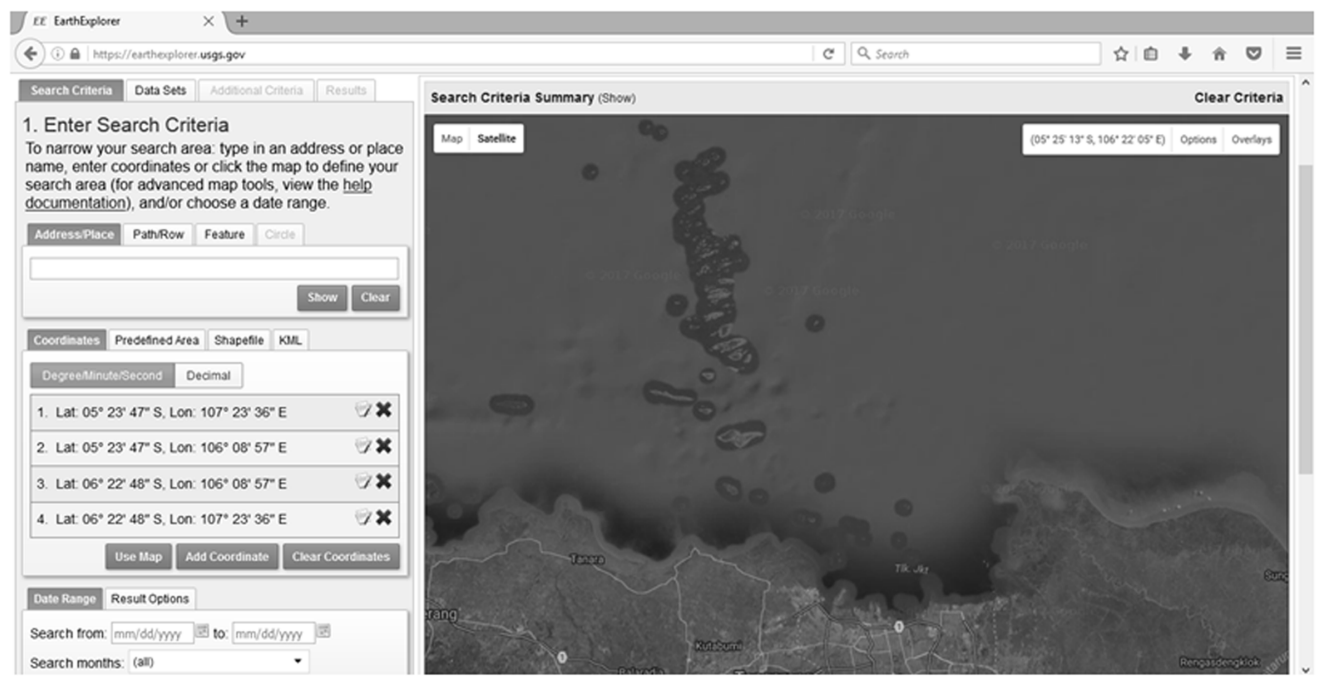

Gambar 6. Pemilihan Area of Interest (AOI) yang ingin dicari data citra satelit. 
5. Tentukan rentang waktu citra yang ingin diunduh. Sebagai contoh pada rentang waktu dari 1 Januari
2017 hingga 1 Juni 2017. Lalu klik tombol Dataset yang berada di kiri bawah jendela browser.

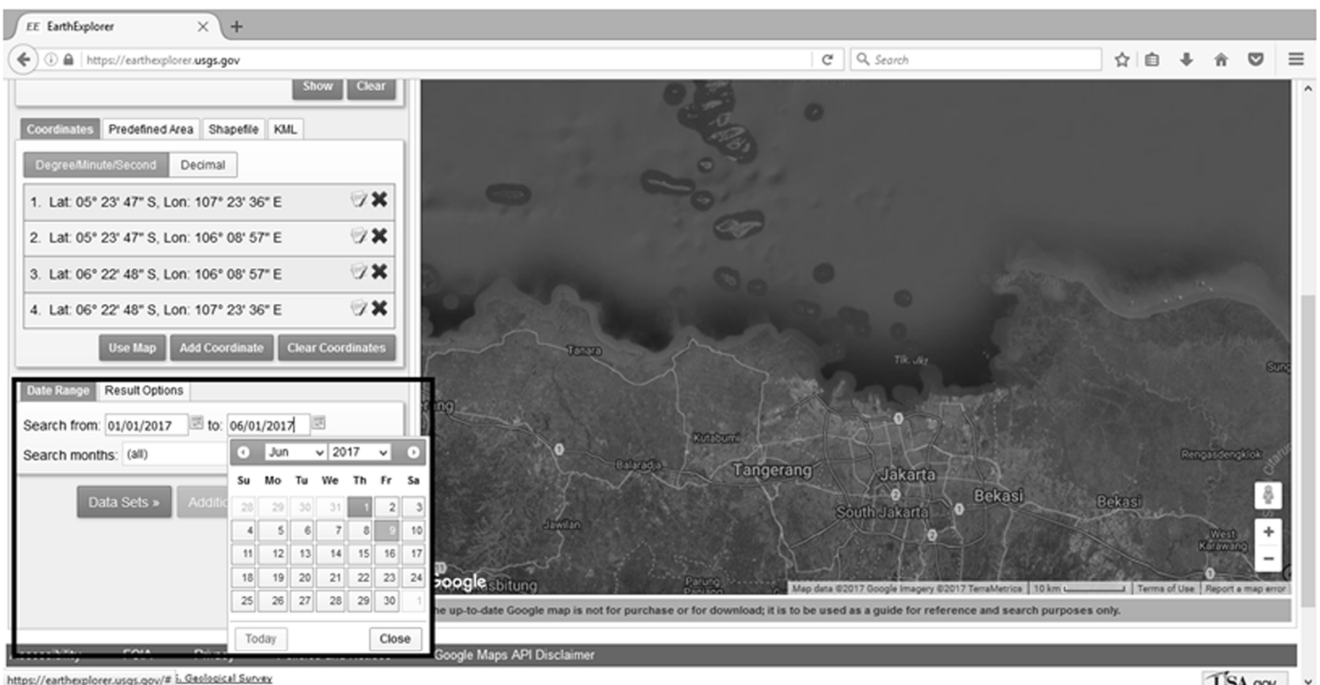

Gambar 7. Pemilihan rentang waktu pengambilan citra

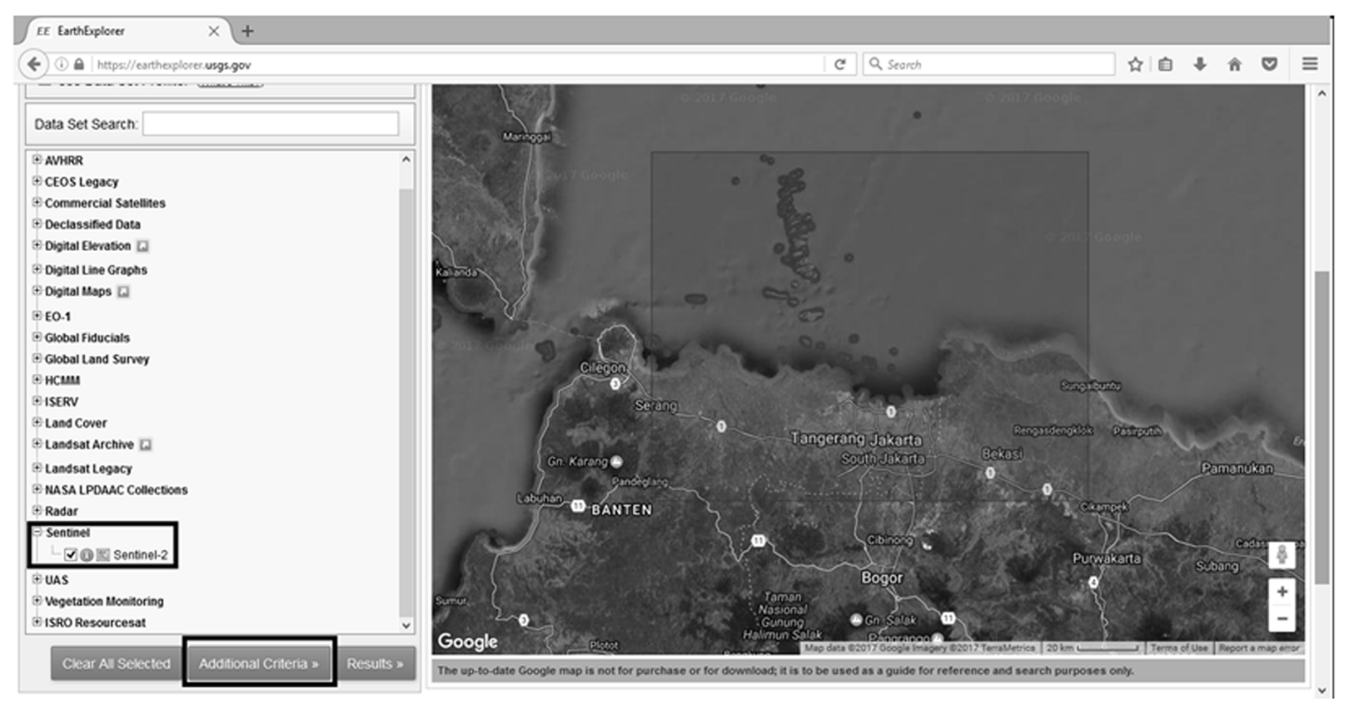

Gambar 8. Pemilihan dataset citra yang ingin diunduh

7. Pada bagian Additional Criteria, kita tentukan kriteria tutupan awan kurang dari 10\% agar citra yang didapatkan bersih dari awan. Kemudian tekan tombol Results. 


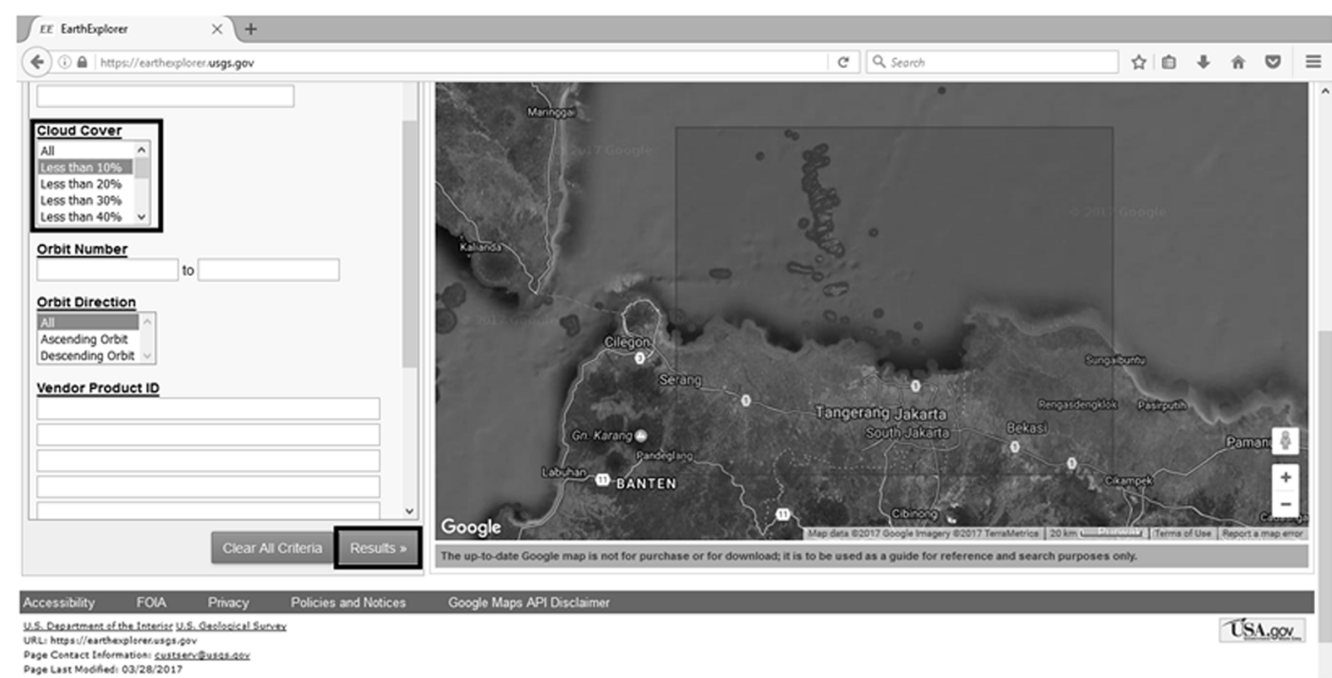

Gambar 9. Pemilihan kriteria tutupan awan

8. Hasil pencarian citra yang diinginkan akan muncul di sisi kiri jendela browser. Kita tinggal memilih citra yang ingin diunduh.

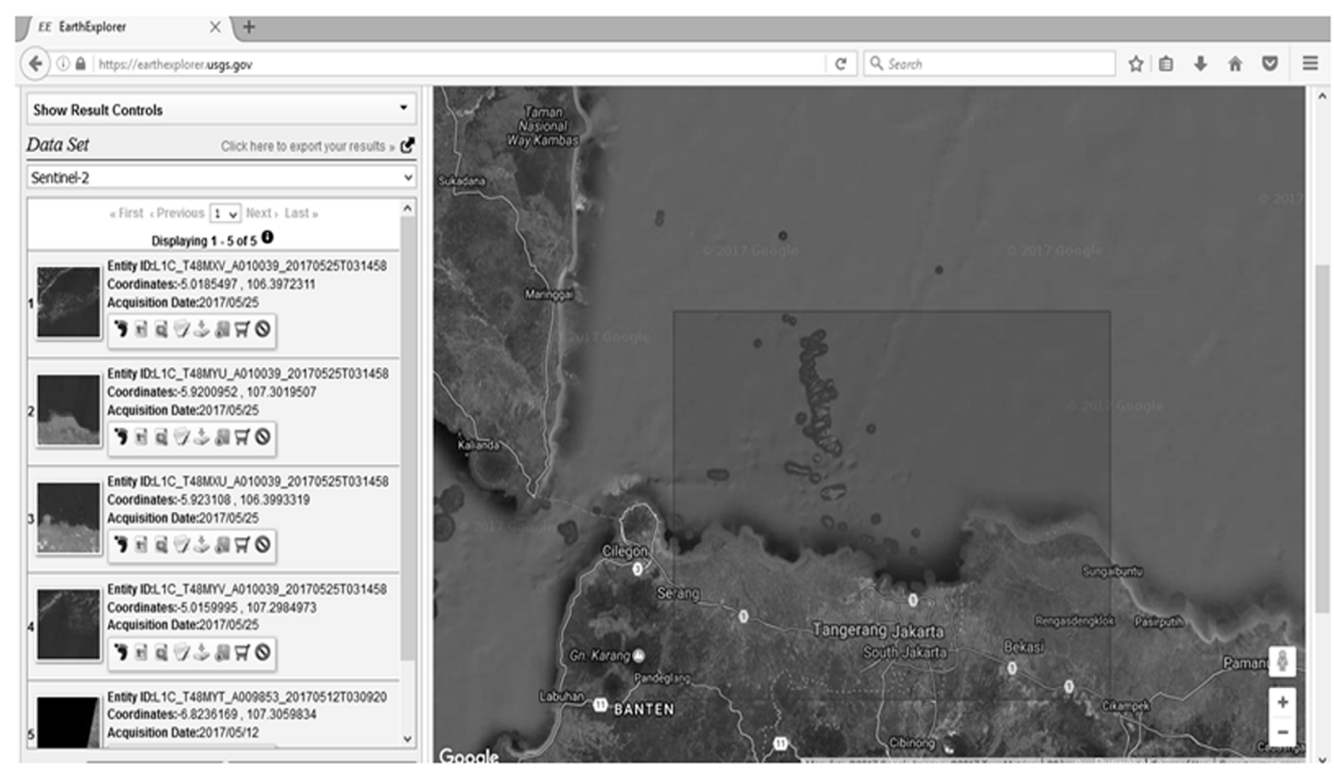

Gambar 10. Hasil pencarian citra Sentinel-2 pada daerah yang diinginkan 
9. Kita dapat menekan icon preview 프

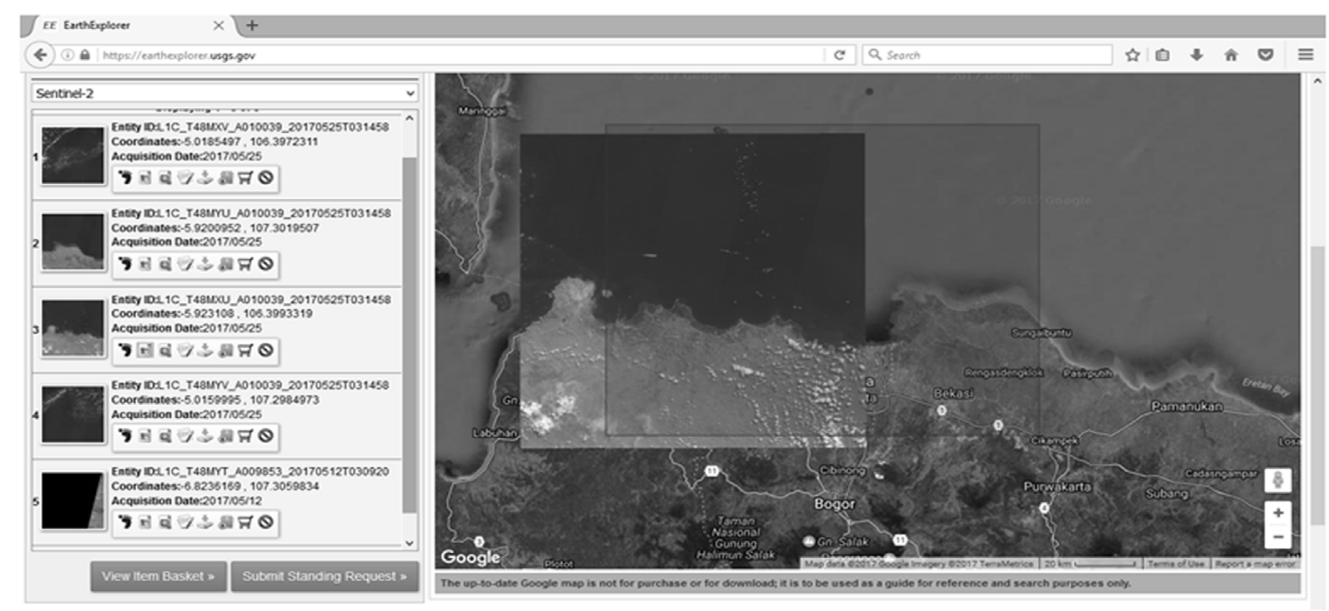

Gambar 11. Tampilan preview (pratinjau) citra yang akan diunduh

10. Pengunduhan dapat dilakukan dengan menekan icon dan akan muncul pop up window yang berisikan opsi pengunduhan. Pilih
L1C Tile in JPEG2000 format (631.3 MB) untuk mendapatkan citra semua kanal Sentinel-2.

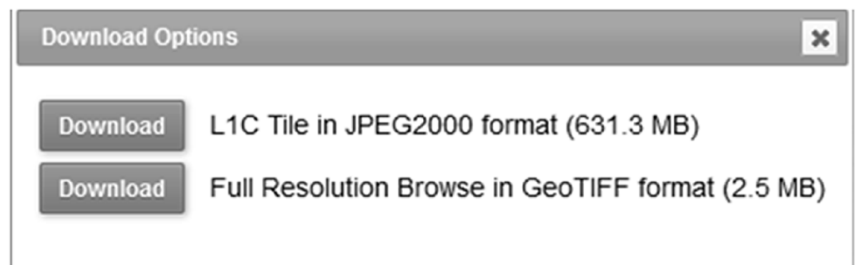

Gambar 12. Opsi pengunduhan citra Sentinel-2

11. Citra yang sudah diunduh akan berisikan file-file seperti berikut ini.

\begin{tabular}{|c|c|c|c|}
\hline Name & Date modified & Type & Size \\
\hline [ T48MXU_20170525T025551_B01.jp2 & $5 / 25 / 20174: 15$ AM & JP2 File & $2,867 \mathrm{~KB}$ \\
\hline T48MXU_20170525T025551_B02.jp2 & $5 / 25 / 20174: 20$ AM & JP2 File & $88,631 \mathrm{~KB}$ \\
\hline T48MXU_20170525T025551_B03.jp2 & $5 / 25 / 20174: 20 \mathrm{AM}$ & JP2 File & $87,639 \mathrm{~KB}$ \\
\hline T48MXU_20170525T025551_B04.jp2 & $5 / 25 / 2017$ 4:20 AM & JP2 File & $90,753 \mathrm{~KB}$ \\
\hline [ T48MXU_20170525T025551_B05.jp2 & $5 / 25 / 20174: 20 \mathrm{AM}$ & JP2 File & $24,942 \mathrm{~KB}$ \\
\hline [ T48MXU_20170525T025551_B06.jp2 & $5 / 25 / 20174: 20$ AM & JP2 File & $26,553 \mathrm{~KB}$ \\
\hline D T48MXU_20170525T025551_B07.jp2 & $5 / 25 / 20174: 20$ AM & JP2 File & $27,483 \mathrm{~KB}$ \\
\hline [ T48MXU_20170525T025551_B08.jp2 & $5 / 25 / 20174: 20$ AM & JP2 File & $98,950 \mathrm{~KB}$ \\
\hline — T48MXU_20170525T025551_B8A.jp2 & $5 / 25 / 20174: 20$ AM & JP2 File & $28,296 \mathrm{~KB}$ \\
\hline T48MXU_20170525T025551_B09.jp2 & $5 / 25 / 20174: 15$ AM & JP2 File & $2,693 \mathrm{~KB}$ \\
\hline D T48MXU_20170525T025551_B10.jp2 & $5 / 25 / 20174: 15$ AM & JP2 File & $1,584 \mathrm{~KB}$ \\
\hline - T48MXU_20170525T025551_B11.jp2 & $5 / 25 / 20174: 20 \mathrm{AM}$ & JP2 File & $26,115 \mathrm{~KB}$ \\
\hline 口 T48MXU_20170525T025551_B12.jp2 & $5 / 25 / 20174: 20 \mathrm{AM}$ & JP2 File & $25,741 \mathrm{~KB}$ \\
\hline [ T48MXU_20170525T025551_TCl.jp2 & $5 / 25 / 2017$ 4:31 AM & JP2 File & $113,951 \mathrm{~KB}$ \\
\hline
\end{tabular}

Gambar 13. File semua kanal citra Sentinel-2 beserta metadatanya. 


\section{via Earth Observing System}

1. Masuk ke halaman web https:// lv.eosda.com

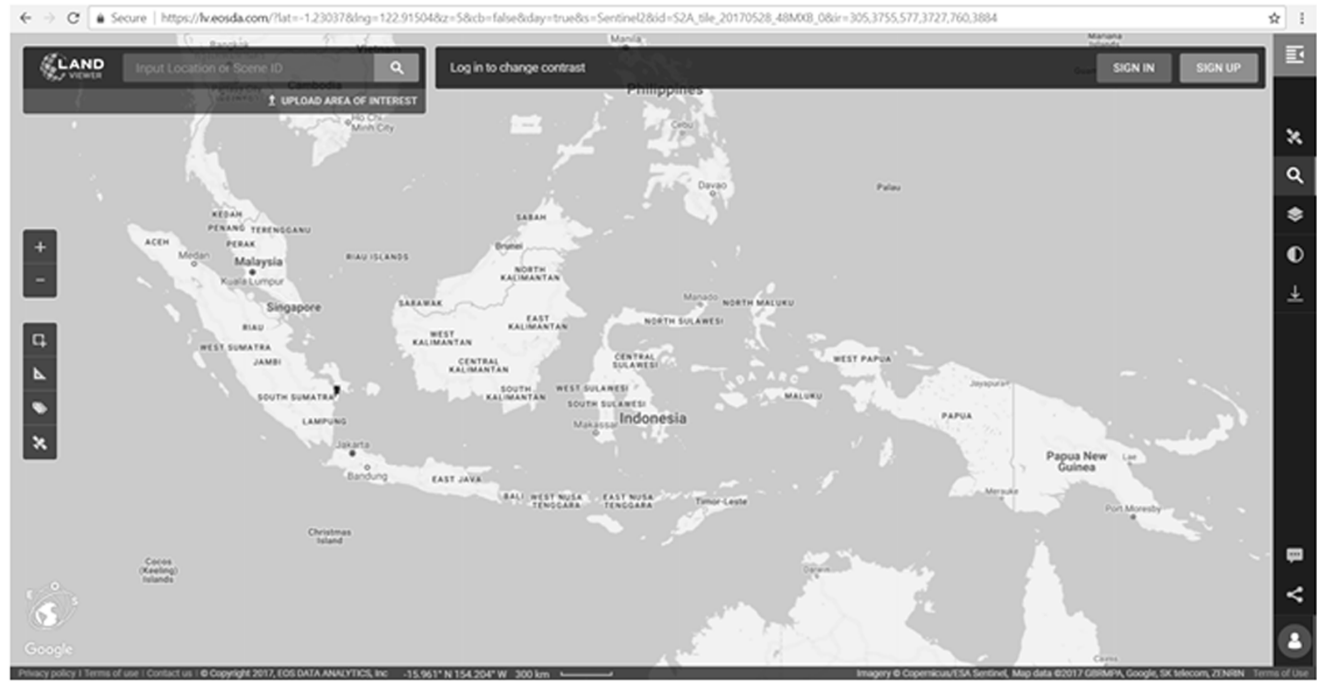

Gambar 14. Halaman utama Earth Observing System

2. Pilih Sign in atau Sign Up. Akan toolbar yang yang berada di sebelah muncul icon pemilik akun pada kanan-bawah pada tampilan layar.

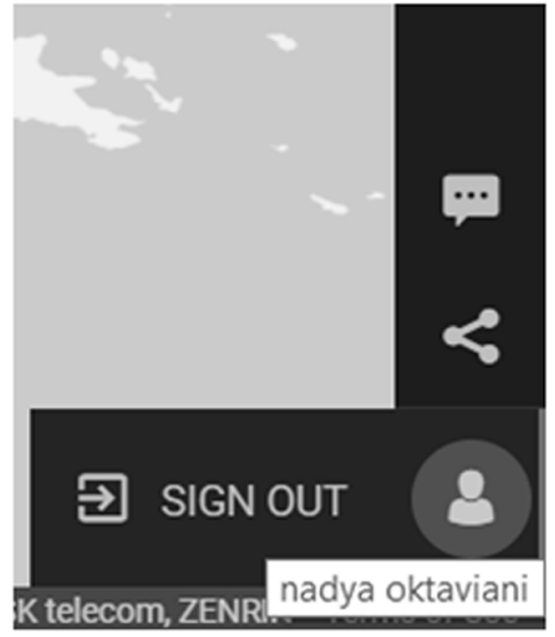

Gambar 15. Tampilan pemilik akun yang telah melakukan login

3. Tentukan satelit yang ingin anda cari datanya, yaitu Sentinel 2. 


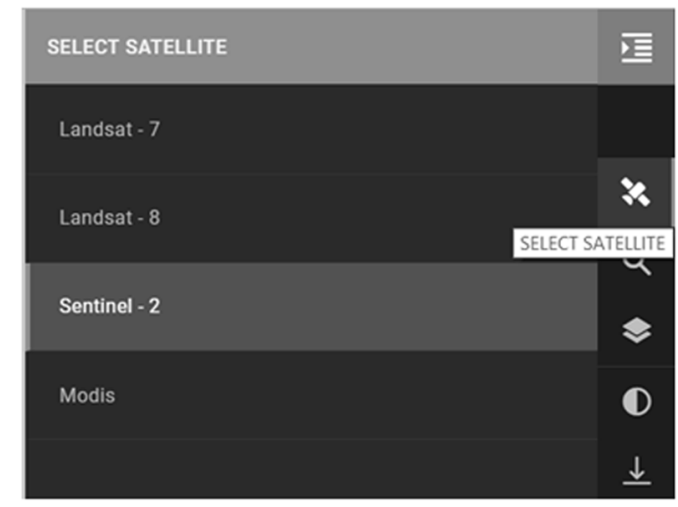

Gambar 16. Pemilihan citra satelit yang akan diunduh

4. Pengguna hanya cukup melakukan Zoom-in pada wilayah yang akan dicari citranya. Secara otomatis sistem akan mencarikan citra Sentinel-2 pada daerah tersebut. Kemudian akan muncul beberapa pilihan citra yang tersedia pada lokasi yang dimaksud (sebagai contoh pada wilayah Sulawesi Utara) di sisi kanan jendela browser. Pilihlah citra yang tutupan awannya tidak terlalu banyak.

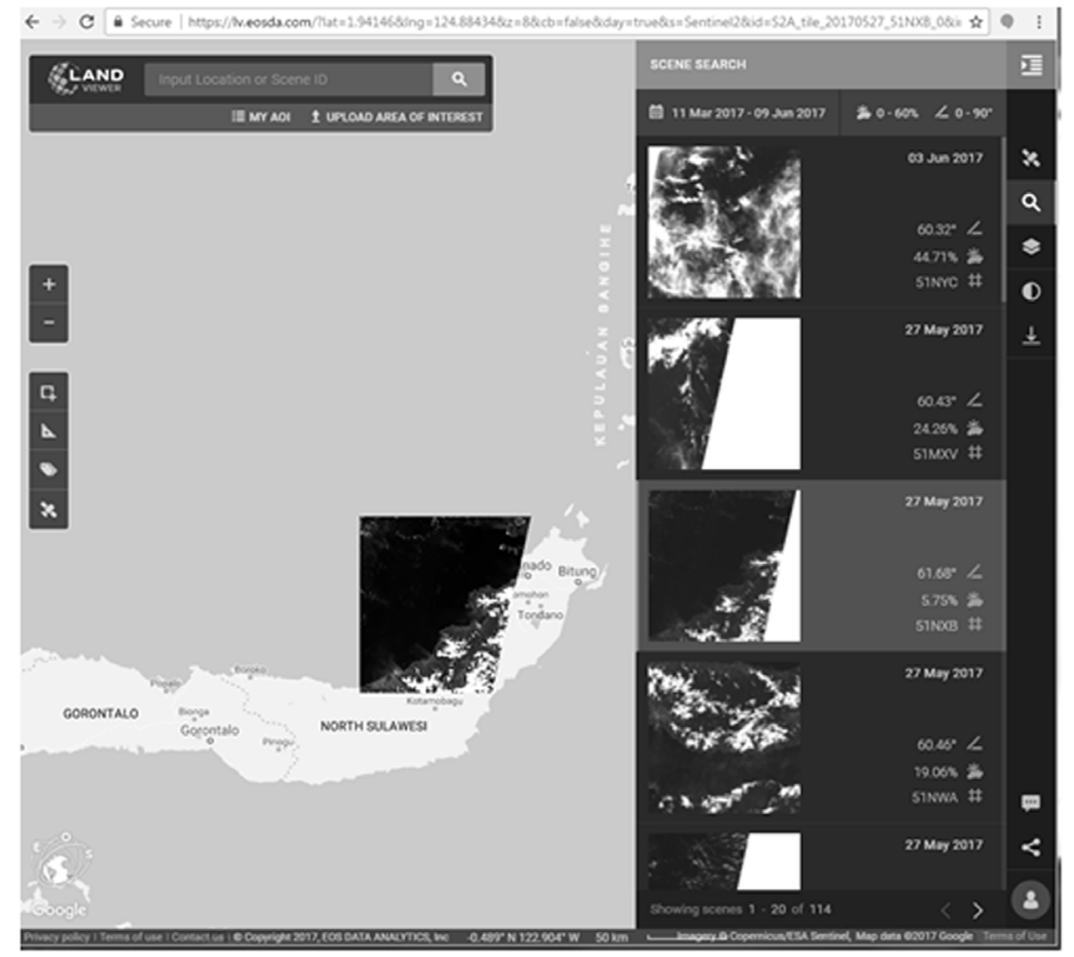

Gambar 17. Pilihan scene citra Sentinel-2 di daerah yang diinginkan 
5. Pengguna dapat memilih rentang tutupan awan dan elevasi matahari dengan menekan icon $\approx 0-10 \% \quad \angle 0-90^{\circ}$ pada sisi kanan atas. Caranya cukup dengan menggeser garis tegak yang ada pada bagian tutupan awan dan elevasi matahari untuk menentukan rentang yang diinginkan.

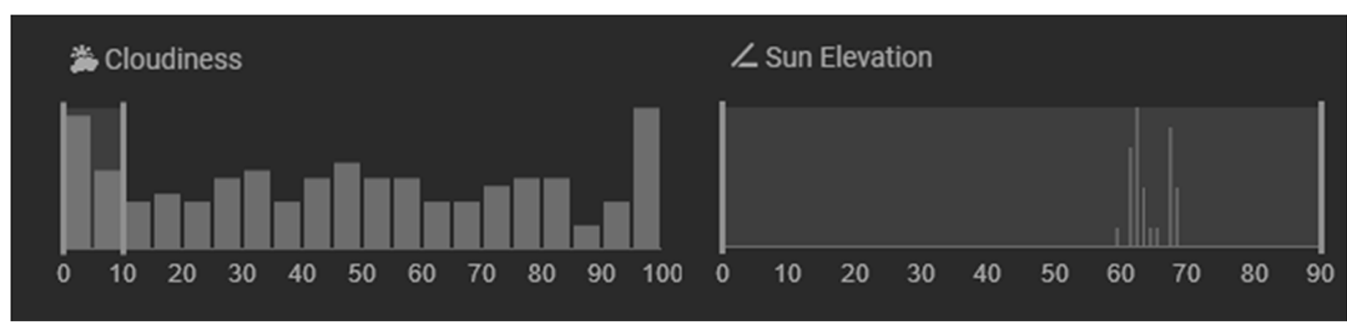

Gambar 18. Pengubahan rentang tutupan awan dan elevasi matahari

6. Pengguna juga bisa mengatur diunduh. rentang waktu citra yang akan

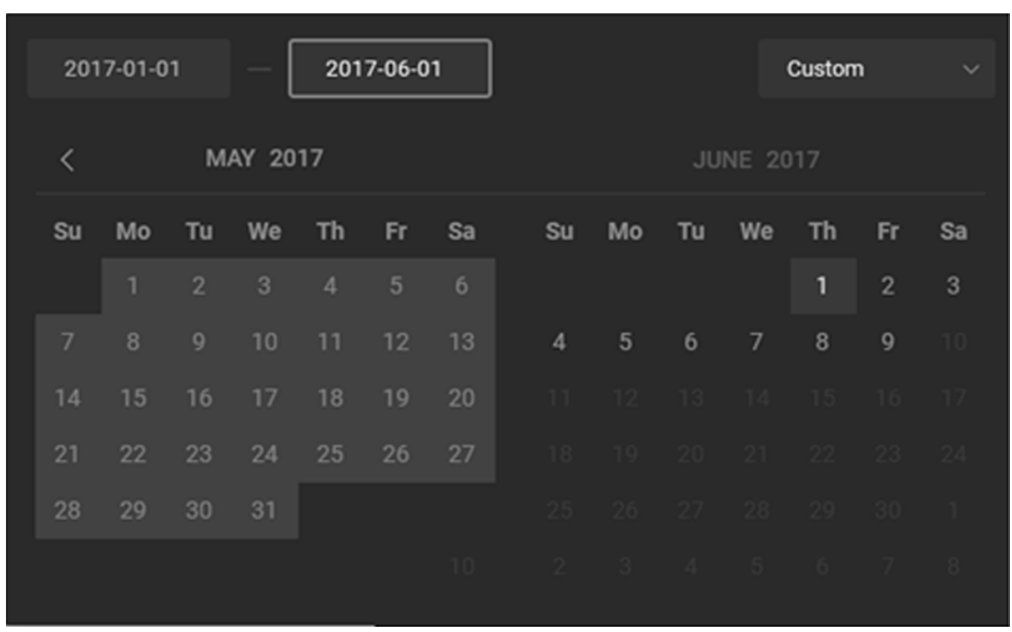

Gambar 19. Pengaturan rentang waktu citra yang akan diunduh

7. Saat memilih citra yang akan diunduh, terdapat beberapa informasi mengenai citra Sentinel-2 tersebut, diantaranya:

a. Perekaman citra, dilakukan pada tanggal 27 Mei 2017 b. Sudut kemiringan pengambilan gambarnya, sebesar $61.68 \square$

c. Besarnya tutupan awannya, sebesar $5.75 \%$

d. Terletak pada zona serta path/ row, $51 \mathrm{NXB}$ 


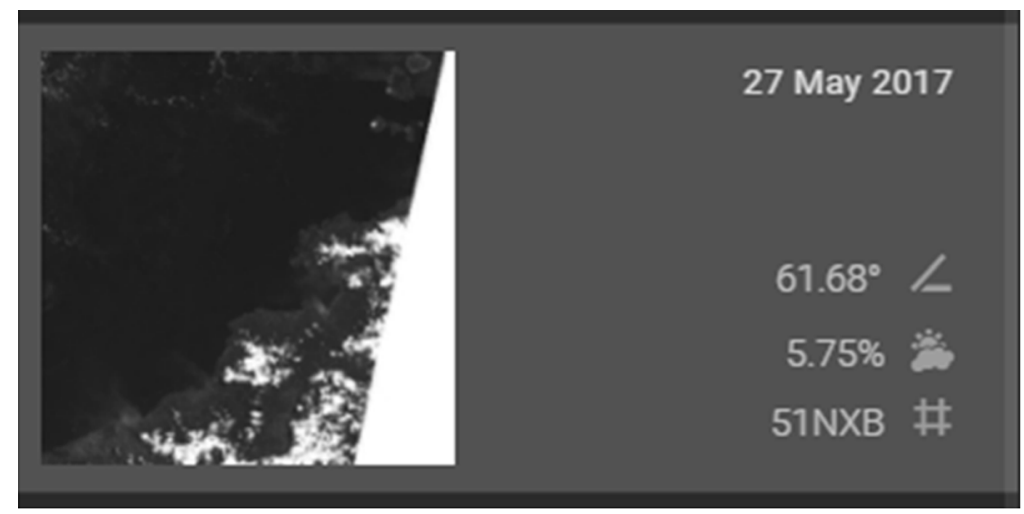

Gambar 20. Informasi mengenai citra yang akan diunduh

8. Pengunduhan semua kanal citra Sentinel-2 bisa dengan cara langsung memilih Scene Downloading yang berada pada sisi kanan jendela browser. Pengunduhan dilakukan pada tiap kanalnya.

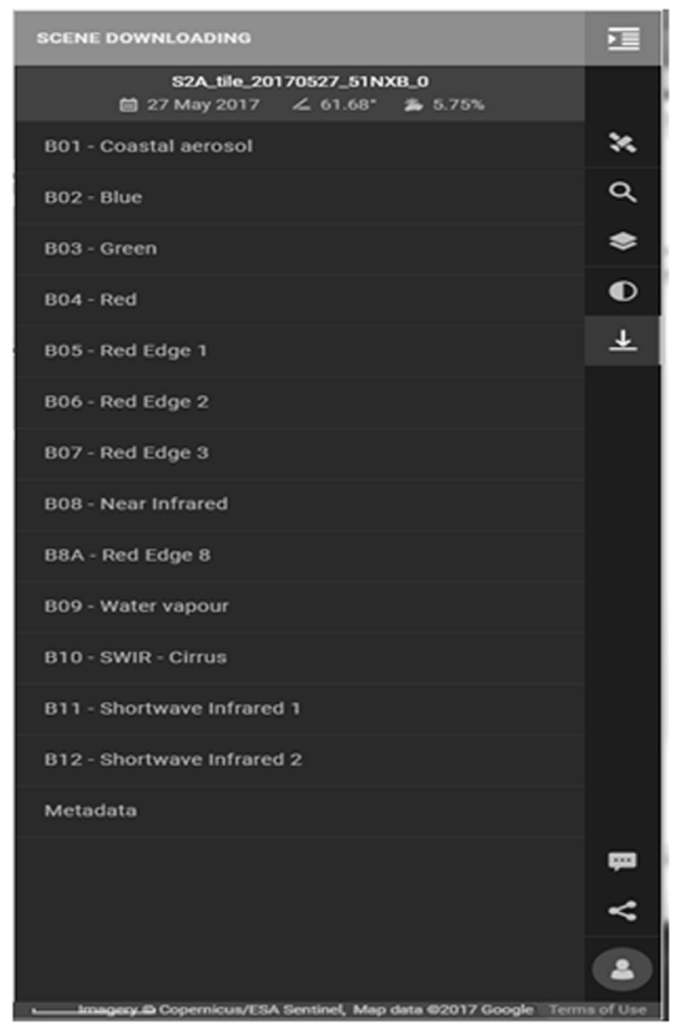

Gambar 21. Tampilan unduhan semua kanal citra Sentinel-2 
9. Kanal citra yang telah diunduh akan tersimpan sebagai file JPEG2000

\begin{tabular}{|c|c|c|c|}
\hline 事 B01 & $02 / 06 / 201712: 45$ & ACDSee 10.0 JP2 I... & $2.493 \mathrm{~KB}$ \\
\hline 贯 B02 & $02 / 06 / 201713: 10$ & ACDSee $10.0 \mathrm{JP} 2 \mathrm{~L} . .$. & $72.175 \mathrm{~KB}$ \\
\hline 贯 B03 & $02 / 06 / 201713: 10$ & ACDSee 10.0 JP2 $1 . .$. & $70.314 \mathrm{~KB}$ \\
\hline 贯 B04 & $02 / 06 / 201713: 09$ & ACDSee $10.0 \mathrm{JP} 2 \mathrm{I} .$. & $67.887 \mathrm{~KB}$ \\
\hline 圈 B05 & $02 / 06 / 201712: 47$ & ACDSee $10.0 \mathrm{JP} 2 \mathrm{I} . .$. & $19.841 \mathrm{~KB}$ \\
\hline 圆 B06 & $02 / 06 / 201712: 47$ & ACDSee $10.0 \mathrm{JP} 2 \mathrm{~L} .$. & $21.229 \mathrm{~KB}$ \\
\hline 审 B07 & $02 / 06 / 201712: 47$ & ACDSee $10.0 \mathrm{JP} 2 \mathrm{I} . .$. & $21.810 \mathrm{~KB}$ \\
\hline 圈 B08 & 02/06/2017 13:11 & ACDSee 10.0 JP2 I... & $74.238 \mathrm{~KB}$ \\
\hline B & $02 / 06 / 201712: 49$ & ACDSee 10.0 JP2 I... & $22.197 \mathrm{~KB}$ \\
\hline 悬 B09 & $02 / 06 / 201713: 07$ & ACDSee 10.0 JP2 I... & $2.221 \mathrm{~KB}$ \\
\hline 道 B10 & $02 / 06 / 201712: 49$ & ACDSee $10.0 \mathrm{JP} 2 \mathrm{~L} . .$. & $1.310 \mathrm{~KB}$ \\
\hline$B 11$ & $02 / 06 / 201712: 51$ & ACDSee $10.0 \mathrm{JP} 2 \mathrm{I} . .$. & $19.363 \mathrm{~KB}$ \\
\hline 贯 B12 & $02 / 06 / 201712: 52$ & ACDSee 10.0 JP2 I... & $18.738 \mathrm{~KB}$ \\
\hline metadata & 05/06/2017 12:30 & Tert Document & $425 \mathrm{~KB}$ \\
\hline
\end{tabular}

Gambar 22. File semua kanal citra Sentinel 2 beserta metadata

Dari langkah-langkah yang telah dijelaskan di atas, kita dapat memperoleh seluruh kanal citra Satelit Sentinel-2. Selanjutnya, pengguna melakukan koreksi geometrik dan radiometrik untuk pemrosesan citra lebih lanjut sesuai dengan penelitian yang akan dilakukan.

\section{PENUTUP}

Sentinel-2 sebagai citra satelit yang baru diluncurkan memberikan alternatif kepada pengguna untuk memperoleh data citra dengan resolusi spasial, temporal, radiometrik, dan spektral yang cukup baik jika dibandingkan SPOT dan Landsat. Selain itu, Sentinel-2 dapat diunduh secara gratis dan mudah oleh masyarakat umum. Keberadaan citra Sentinel-2 diharapkan mampu dioptimalkan penggunaannya terutama untuk analisa penginderaan jauh terutama di bidang kelautan. dan metadata berupa text file.

\section{DAFTAR PUSTAKA}

Berger, M., J. Moreno, J. A. Johannessen, P. F. Levelt and R. F. Hanssen. 2012. ESA's sentinel missions in support of Earth system science. Remote Sensing of Environment 120 (2012) 84-90.

Drusch, M., U. D. Bello, S. Carlier, O. Colin, V. Fernandez, F. Gascon, B. Hoersch, C. Isola, P. Laberinti, P. Martimort, A. Meygret, F. Spoto, O. Sy, F. Marchese and P. Bargellini. 2012. Sentinel-2: ESA's Optical High-Resolution Mission for GMES Operational Services. Remote Sensing of Environment 120 (2012) : 25-36.

European Space Agency. 2012. ESA's Optical High-Resolution Mission for GMeS Operational Services. ESA Communication, Noordwijk: 80 hlm. 
European Space Agency. 2015. Sentinel-2 User Handbook Revision 2. ESA Communication, Noordwijk: 64 hlm.

European Space Agency. 2017b. Sentinel-2 [online]. https:// earth.esa.int/web/guest/ missions /esa-operationaleo-missions/sentinel-2.html. Diakses pada tanggal 8-6-2017.

European Space Agency. 2017a. Sentinels High Level Operations Plan. Copernicus Space Component Mission Management Team, Frascati: $75 \mathrm{hlm}$.

Hedley, J., C. Roelfsema, B. Koetz, and S. Phinn. 2012. Capability of the Sentinel 2 mission for tropical coral reef mapping and coral bleaching detection. Remote Sensing of Environment 120 (2012) : 145-155.
Malenovský, Z., H. Rott, J. Cihlar, M. E. Schaepman, G. García-Santos, R. Fernandes and M. Berger. 2012. Sentinels for science: Potential of Sentinel-1, -2, and -3 missions for scientific observations of ocean, cryosphere, and land. Remote Sensing of Environment 120 (2012) : 91-101.

Van der Meer, F.D., H.M.A. van der Werff and F.J.A. van Ruitenbeek. 2014. Potential of ESA's Sentinel-2 for geological applications. Remote Sensing of Environment 148 (2014) : 124-133.

Verrelst, J., J. Muñoz, L. Alonso, J. Delegido, J.P. Rivera, G. Camps-Valls and J. Moreno. 2012. Machine learning regression algorithms for biophysical parameter retrieval: Opportunities for Sentinel-2 and -3. Remote Sensing of Environment 118 (2012) : 127 139. 